\title{
Histone Deacetylase 4
}

National Cancer Institute

\section{Source}

National Cancer Institute. Histone Deacetylase 4. NCI Thesaurus. Code C19673.

Histone deacetylase 4 (1084 aa, $119 \mathrm{kDa}$ ) is encoded by the human HDAC4 gene. This protein plays a role in the regulation of cell differentiation and histone deacetylation. 